\title{
PENGEMBANGAN INSTRUMEN ASESMEN KINERJA DASAR TATA RIAS
}

\author{
Oleh: I Gede Sudirtha \\ Jurusan Pendidikan Kesejahteraan Keluarga Fakultas Teknik dan Kejuruan \\ Universitas Pendidikan Ganesha \\ sudirthaG@yahoo.com
}

\begin{abstract}
ABSTRAK
Penelitian ini bertujuan untuk mengembangkan instrumen asesmen kinerja untuk Mata Kuliah Praktek Dasar Tata Rias di Program Studi Pendidikan Tata Kecantikan dengan langkahlangkah validitas dan reliabilitas yang tepat. Penelitian ini merupakan penelitian pengembangan dengan fokus penelitian pengembangan perangkat asesmen Mata Kuliah Praktek Dasar Tata Rias. Aspek-aspek penelitian terkait dengan konstruksi tes dan validasi intrumen dilakukan dengan teknik studi pustaka dan panel ahli (expert judgement). Data penelitian berupa data kuantitatif, dan dianalisis dengan statistik yang terkait dengan validitas dan reliabilitas instrumen. Hasil penelitian menunjukkan : 1) perangkat instrumen dikembangkan melalui tahap analisis kebutuhan instrumen. Analisis kebutuhan ini dilakukan melalui kajian pustaka dan kajian terhadap kompetensi mata kuliah dengan tim peneliti dan pengajar mata kuliah. Kajian ini menghasilkan kisi-kisi, dan perangkat instrument beserta pedoman penskorannya. Tahap berikutnya dilakukan validasi instrumen melaui expert judgement untuk membuktikan validitas isi perangkat instrumen yaitu kesesuaian antara dimensi penilaian, indikator, dan deskriptor. Validitas konstruk dan reliabilitas perangkat dilakukan melalui uji coba instrumen pada mahasiswa Program studi Tata Kecantikan. Selanjutnya dilakukan uji content validity dengan formula Gregory dan uji reliabilitas dengan formula Alpha Cronbach. Dari 5 perangkat instrumen tes kinerja yang dikembangkan menunjukkan validitas $\left(\mathrm{r}_{\mathrm{xy}}>0.30\right)$ dan reliabilitas $\left(\mathrm{r}_{\mathrm{xx}}>\right.$ 0,6 ). Koefisien ini menunjukkan bahwa perangkat instrumen memiliki validitas dan reliabilitas yang dapat diandalkan untuk mengukur kinerja praktek dasar tata rias. 2) Prosedur Penggunaan Perangkat Instrumen Asesmen Mata Kuliah Praktek Dasar Tata Rias perlu penyederhanaan konsep asesemen yang mengarah kepada prosedur yang lebih praktis dan efisien.
\end{abstract}

Kata - kata kunci : instrumen asesmen, pengembangan,praktek tata rias

\begin{abstract}
This study aims to develop a performance assessment instrument for Make up Training Subject in Beauty Education Program by appropriate validity and reliability procedure in the development of the assessment instrument as the assessment process and products. This research is a development research (R\&D). The research focuses on the development of assessment instrument for Makeup Training Subject. The aspects of research, data sources, techniques and instruments/data collection instrument, and validation and reliability of the instrument used in the study conducted by interview, observation, and literature and documents. The data of this study is quantitative data, which was statistically analyzed due to relevant empirical testing (validation of instruments) that includes testing and content validity and internal validity. Descriptive analyzes were undertaken to describe the research data. The results showed: 1) The design of the instrument Makeup Training Subject are developed through the needs analysis. It is done through literature review and study of the course competencies by engaging a team of researchers. This study resulted in the instrument guidelines and assessment instrument completed with its scoring rubrics. The instrument comprising: a step of validity assessment is done through the stages: experts judgment, empirical tests to prove the validity and reliability of the instruments assessment. All the performance test instrument developed is
\end{abstract}

Pengembangan Instrumen Asesmen Kinerja .......................... ( I Gede Sudirtha) 
valid $\left(\mathrm{r}_{\mathrm{xy}}>0.30\right)$ and reliable $\left(\mathrm{r}_{\mathrm{xx}}>0.60\right)$. Assessment instruments besides the assessment process and results of this study have had a fit between indicators and their assessment dimensions and descriptors. 2) for implementation asessmen in the classroom, it is necessary to obtain a simplification of procedures asesemen concept is more practical and efficient.

Keywords : assessment instruments, develope, the practice of cosmetology

\section{PENDAHULUAN}

Seseorang dapat disebut kompeten (memiliki kemampuan) dalam bidang kecantikan, seperti yang dijelaskan di atas harus memiliki pengetahuan, sikap dan keterampilan yang diperolehnya melalui pengalaman langsung atau melalui kegiatan yang dipraktekan, atau dilatihkan. Kompeten atau tidaknya mahasiswa dapat dibuktikan dari ketuntasan hasil belajar yang dialami mahasiswa melalui penilaian proses dan hasil belajar yang ditunjukkan melalui bukti-bukti hasil belajar.

Untuk dapat mengetahui perkembangan hasil belajar mahasiswa selama proses dan di akhir peembelajaran terutama terkait aspek keterampilan dalam pembelajarann praktek, sangat dibutuhkan kemampuan pengelolaan asesemen pembelajaran yang tepat dan otentik sesuai karakteristik materi pembelajaran. Atas dasar itu perlu adanya tindakan nyata dalam rangka peningkatan kualitas dan proses belajar. Usaha- usaha ke arah itu telah dilaksanakan oleh dosen di jurusan Pendidikan Kesejahteraan Keluarga terutama pada tataran pengelolaan pembelajaran, namun dalam tataran pengembangan alat/ instrumen penilaian masih belum banyak dilakukan.

Bukti hasil belajar mahasiswa tata kecantikan secara langsung dapat diperoleh melalui proses dan hasil belajarnya. Bukti hasil belajar tersebut dapat berupa produk atau jasa layanan kecantikan. Untuk menghasilkan produk atau jasa yang baik, layak, dan sesuai standar, proses belajar mahasiswa harus diarahkan pada pencapaian kepuasan pelanggan/client atau sesuai dengan selera pelanggan. Hal ini sangat sesuai dengan konsep dari pembelajaran berbasis produksi, seperti yang telah diteliti sebelumnya berupa "Implementasi Pembelajaran berbasis produksi melalui media dan sumber belajar kontekstual pada mahasiswa Program Studi Pendidikan Tata Busana FPTK IKIP Negeri Singaraja" menunjukkan hasil yang baik. Dalam siklus I maupun II terhitung lebih dari $85 \%$ mahasiswa dinyatakan memperoleh nilai lulus. Pada siklus satu terhitung $87 \%$ dan siklus II $100 \%$. Dilihat dari perolehan nilai A dan B dalam siklus I dan II juga menunjukkan perbandingan yang lebih besar dari perolehan nilai C. Pada siklus I terlihat $4: 3$, siklus II terlihat $5: 3$. Dengan demikian hasil penelitian ini menunjukkan pembelajaran berbasis produksi melalui media dan sumber belajar kontekstual pada mahasiswa Program Studi Pendidikan Tata Busana FPTK IKIP Negeri Singaraja dapat meningkatkan (1) kesiapan belajar mahasiswa dalam mengikuti pembelajaran di kelas, (2) aktivitas belajar mahasiswa, (3) kualitas proses dan hasil belajar mahasiswa (Sudirtha dan Agus Mayuni, 2007).

JPTK, UNDIKSHA, Vol. 11, No. 2, Juli 2014 : 63 - 74 
Belum ada instrumen evaluasi yang baku untuk mengukur keahlian pada Mata Kuliah Praktek Tata Kecantikan. Untuk memberikan skor cenderung bersifat subyektif, bahkan asesmen tidak dilaksanakan secara bertahap sesuai dengan langkah-langkah yang harus dilakukan untuk melakukan/menciptakan produk/ jasa kecantikan. Semestinya proses yang dilakukan mahasiswa dari awal sampai akhir sudah dievaluasi dengan suatu asesmen yang jelas dan standar.

Hasil kajian dalam penelitian Yoyoh Jubaedah, 2009 menyatakan pelaksanaan penilaian berkala level kualifikasi untuk menilai capaian kompetensi peserta didik sebagai hasil belajar di SMK, pada umumnya belum menggunakan model penilaian yang mengakomodasi alat penilaian yang mengacu pada tuntutan dunia kerja. Alat penilaian yang dirancang dan digunakan oleh guru untuk menilai capaian kompetensi peserta didik masih heterogen pada setiap SMK, sehingga diperlukan alat penilaian yang standar mengacu pada tuntutan penilaian kompetensi meliputi kemampuan kognitif, psikomotor dan afektif. Fenomena ini tergambarkan dari hasil penelitian Jubaedah (2005 : 134) yang berkatian dengan implementasi Competency Based Traning berdasarkan Standar Kompetensi Nasional pada kegiatan pembelajaran di SMK.

Lebih lanjut disimpulkan dalam penelitian ini bahwa : guru paket keahlian (Tata Busana, kecantikan, dan keahlian lainnya) belum siap untuk melaksanakan penilaian secara komprehensif pada keberhasilan belajar peserta didik. Keberhasilan belajar yang komprehensif tersebut meliputi kemampuan kognitif, psikomotor dan afektif dalam pembuatan busana. Ketidaksiapan tersebut teramati dari cara guru dalam melakukan penilaian di dalam kegiatan praktikum, khususnya pada penilaian proses kerja belum menggunakan alat penilaian yang sesuai dengan tuntutan Standar Kompetensi Nasional.

Penanganan hasil belajar mahasiswa, oleh dosen belum memiliki pedoman yang baku dan jelas terkait dengan penilaian maupun prosedur penilaiannya. Penilaian dilakukan dengan alat ukur yang sangat bervariasi, kususnya pada pembelajaran praktek tata busana/ program produktif lainnya. Hal serupa juga terjadi di Sekolah Menengah Kejuruan (SMK). Hal ini ditunjukkan oleh hasil penelitian Yoyoh Jubaedah, 2009, yang pada kesimpulannya menyebutkan: penyelenggaraan penilaian keahlian (Tata Busana/kecantikan) di SMK pada umumnya dilaksanakan pada akhir semester melalui penilaian kompetensi secara internal oleh guru, dan baru satu SMK yang melaksanakan penilaian berkala level kualifikasi yang dilaksanakan oleh guru sebagai penilai internal dan dari pihak industri sebagai penilai eksternal.

Jenis penilaian yang digunakan untuk menilai hasil belajar peserta didik terdiri dari tes tertulis dalam bentuk pilihan ganda dan esai, serta tes tindakan dalam bentuk penilaian produk. 
Alat penilaian yang digunakan untuk tes tertulis berupa daftar pertanyaan tertulis dan untuk tes tindakan berupa tugas kerja. Pengumpulan bukti penilaian kompetensi pada tes tindakan pada umumnya belum menggunakan alat dan pedoman penilaian yang spesifik sesuai kriteria kinerja yang harus dinilai pada kualifikasi materi yang diujikan.

Konsekuensi yang terjadi dari penilaian yang dilakukan sebelumnya pada capaian hasil belajar keahlian belum sepenuhnya dapat menggambarkan kemampuan yang sebenarnya. Melihat kenyataan seperti itu, nampaknya perlu dikembangkan satu model asessmen yang jelas untuk dapat mengukur kinerja mahasiswa dengan sesungguhnya.

Asesmen yang dapat mengukur kinerja mahasiswa yang sesungguhnya menuntut mahasiswa menunjukkan kinerja, bukan menjawab atau memilih jawaban dari sederetan kemungkinan jawaban yang telah disediakan. Asesmen yang sesungguhnya perlu digunakan dalam pembelajaran agar mahasiswa dapat menunjukkan kemampuannya secara langsung terhadap proses dan hasil belajar.

Kenyataan menunjukkan bahwa belum ada evaluasi yang baku untuk mengukur keahlian pada mata kuliah praktek tata rias. Pemberian skor cenderung subyektif, bahkan asesmen tidak dilaksanakan secara bertahap sesuai dengan langkah-langkah yang harus dilakukan untuk menciptakan suatu busana. Semestinya proses yang dilakukan mahasiswa dari awal sampai akhir sudah dievaluasi dengan suatu asesmen yang jelas dan standar. Penilaian yang dilakukan belum sepenuhnya dapat menggambarkan kemampuan yang sebenarnya. Melihat kenyataan seperti itu, nampaknya perlu dikembangkan satu model asessmen yang jelas untuk dapat mengukur kinerja dan hasil praktek mahasiswa yang sesungguhnya.

Asesmen otentik harus mampu mengukur kinerja mahasiswa, bukan mengukur apa yang harus dijawab atau dipilih sebagai jawaban dari sederetan kemungkinan jawaban yang telah disediakan. Asesmen otentik sangat perlu digunakan dalam pembelajaran agar mahasiswa dapat menunjukkan kemampuannya secara langsung terhadap proses dan hasil belajar.

Asesmen otentik dapat memperbaiki proses pembelajaran, karena asesmen dapat membantu para dosen dalam membuat keputusan-keputusan selama proses pembelajaran (Fuchs, 1995). Setidaknya ada tiga keputusan yang harus dibuat dosen, yaitu penempatan, formatif, dan diagnostik. Ketiga bentuk keputusan tersebut sangat membantu proses pembelajaran, sehingga mencapai tujuan yang telah ditetapkan.

Orientasi penelitian ini adalah pengembangan instrument asesmen otentik. Dipilihnya asesmen otentik, karena mata kuliah ini berbasis pengetahuan, konsep, dan keterampilan (skill). Keterampilan ini tepatnya Diases dengan asesmen yang otentik mulai dari proses mendesain sampai menentukan desain kerja yang diorientasikan pada proses produksi.

JPTK, UNDIKSHA, Vol. 11, No. 2, Juli 2014 : 63 - 74 
Penelitian ini merupakan penelitian pengembangan yang menghasilkan perangkat instrumen asesmen yang dapat dipakai sebagai acuan dalam mengevaluasi proses dan hasil belajar untuk Mata Kuliah Praktek dasar Tata Rias.

Alur penelitian yang dilakukan dengan model rancangan yang diadopsi dari model rancangan Dick and Carey. Model ini merupakan seperangkat prosedur yang berurutan untuk mewujudkan suatu proses melaksanakan pengembangan sistem dan alat penilaian. Model ini terdiri dari beberapa bagian/ tahapan yang saling berhubungan, satu bagian/ tahapan sebelumnya memperlihatkan balikan dari tahapan sebelumnya. Setiap tahapan mengacu ke perangkat prosedur dan teknik yang dipakai untuk merancang, memproduksi, memvalidasi, dan mengubah/memperbaiki instrumen. Masalah pokok penelitian ini adalah 1) bagaimana mengembangkan perangkat asesmen sebagai asesmen proses dan produk mata kuliah praktek tata rias pada Progran Studi Pendidikan Tata Kecantikan, 2) bagaimana prosedur penggunaan perangkat instrumen asesmen Mata Kuliah Praktek Tata rias di Program Studi Pendidikan Tata Kecantikan?

\section{METODE PENELITIAN}

Penelitian ini bertujuan untuk mengembangkan perangkat instrumen asesmen sebagai asesmen proses dan produk dalam mata kuliah praktek tata rias di Program Studi Pendidikan Tata Kecantikan. Penelitian ini merupakan penelitian pengembangan (research and development) dengan beberapa tahapan. Subjek penelitian ini adalah mahasiswa Program Studi Pendidikan Tata Kecantikan, dengan fokus penelitian adalah Pengembangan Asesmen Otentik.

Adapun aspek-aspek penelitian, sumber data, teknik dan instrumen/alat pengumpul data, dan validasi dan reliabilitas instrumen yang digunakan dalam penelitian dilakukan dengan teknik wawancara, observasi, dan pencatatan dokumen.

Data penelitian ini berupa data kuantitatif, dan analisis dilakukan dengan analisis statistik. Analisis deskriptif juga dilakukan untuk memberi makna terhadap deskripsi data yang berkaitan dengan keseluruhan tahapan penelitian. Analisis statistik digunakan terkait dengan formula-formula uji empirik (validasi instrumen) yang meliputi uji content validity Analisis statistik digunakan terkait dengan formula-formula uji empirik (validasi instrumen) yang meliputi uji content validity dengan analisis faktor. Indek reliabilitas dihitung dengan koefisien alpha dari Cronbach dan kriteria instrumen yang reliabel ditunjukkan oleh koefisien reliabilitas 


\section{HASIL PENELITIAN DAN PEMBAHASAN}

\subsection{Hasil Penelitian}

\section{a. Pengembangan Perangkat Asesmen}

Langkah-langkah pengembangan instrumen tes kinerja mata kuliah Dasar Tata Rias pada Program Studi Tata Kecantikan Jurusan Pendidikan Kesejahteraan Keluarga Fakultas Teknik dan Kejuruan Universitas Pendidikan Ganesha dilakukan sebagai berikut.

(1) Menetapkan tujuan tes. Adapun tujuan tes kinerja yang dibuat dalam mata kuliah ini adalah untuk mengukur sejumlah keterampilan dan sikap yang harus dikuasai mahasiswa dalam mata kuliah dasar tata rias yang terbentuk mulai dari konsep sampai ke penguasaan keterampilan.

(2) Analisis karakteristik mata kuliah dan analisis bahan/sumber belajar mata kuliah.

(3) Mengembangkan Kompetensi Dasar dan Dimensi/Indikator.

(4) Menyusun Kisi-kisi Tes. Kisi-kisi disusun berdasarkan analisis pada kurikulum Pendidikan Tata Kecantikan yang ada di Jurusan Pendidikan Kesejahteraan Keluarga, serta membandingkan dengan beberapa pembanding berupa buku modul tata kecantikan di sejumlah lembaga pendidikan yang ada seperti dari SMK Tata Kecantikan.

(5) Mengembangkan butir instrumen. Pengembangan instrumen kinerja antara lain : (a) Instrumen Tes Kinerja Merias Wajah Sehari-hari. (b) Instrumen Tes Kinerja Perawatan Kulit Kepala dan Rambut. (c) Instrumen Tes Kinerja Penataan Rambut (sanggul) Kombinasi Tradisional dan Modern. (d) Instrumen Tes Kinerja Melakukan Perawatan Tangan (manicure). (e) Instrumen Tes Kinerja Melakukan Perawatan Kaki (padicure).

(6) Pengujian Validitas Instrumen.

Pengujian validitas instrumen dalam bidang pendidikan dilakukan dalam dua tahap yaitu: Panel Ahli atau expert judgment. Dalam hal ini dilakukan uji kelengkapan, dan uji kesesuaian. Uji ini juga disebut uji validitas non-empirik. Dalam hal ini dimanfaatkan 10 orang ahli. Jawaban para ahli dimanfaatkan untuk menentukan apakah variabel yang dikembangkan sesuai dengan indikator dan deskriptornya, dan selanjutnya dianalisis. Tingkat validitas/kesesuaian tiap butir ditentukan dengan berdasarkan nilai median yang diperoleh dari penillaian panelis dengan ketentuan: Jika seluruh skor panelis memperoleh skor median 1 sampai dengan 3 maka indikator tersebut digugurkan dan perlu diganti, jika seluruh skor panelis memperoleh skor median 4 sampai dengan 6 maka indikator tersebut diperbaiki, dan jika seluruh skor panelis memperoleh skor median 7 sampai dengan 9 berarti butir tes (indikator dan deskriptornya sesuai) dikatakan valid atau sesuai (Soeprijanto, 2010).

Dari hasil hasil penilaian pakar dan perolehan skor median pada butir instrumen kinerja di atas menunjukkan keseluruhan indikator beserta deskriptor yang dikembangkan memperoleh

JPTK, UNDIKSHA, Vol. 11, No. 2, Juli 2014 : 63 - 74 
skor median dengan sebaran antara 7.5 sampai dengan 8.5 , ini berarti butir intrumen kinerja dinyatakan valid/sesuai.

(7) Revisi atau Perbaikan Butir Tes dan Reproduksi Tes Terbatas.

Revisi dilakukan pada beberapa butir yang disarankan oleh para panelis/ pakar. Adapun perbaikan yang disaranklan oleh para pakar adalah menambahkan aspek penilaian produk/ hasil akhir pada setiap instrumen kinerja yang dibuat. Dari lima (5) instrumen kinerja yang dibuat hanya Instrumen Kinerja Penataan Rambut (sanggul) Kombinasi Tradisional dan Modern yang dibuat dengan mencantumkan aspek produk. Selain itu empat instrumen lainnya mendapat koreksi/ masukan seperti yang telah disebut di atas. Revisi kecil lainnya berupa penempatan atau urutan langkah-langkah pada instrumen Instrumen Tes Kinerja Perawatan Kulit Kepala dan Rambut, dan Instrumen Tes Kinerja Penataan Rambut (sanggul) Kombinasi Tradisional dan Modern. Selebihnya perbaikan kecil pada bagian redaksional/ kalimat, dan beberapa butir pernyataan yang perlu diperbaiki dari segi penulisan atau kesalahan cetak.

Selanjutnya setelah mengalami revisi dilakukan reproduksi tes terbatas untuk selanjutnya diuji secara empiris dengan menggunakan 7 orang mahasiswa sebagai sampel.

Analisis butir soal instrumen dimaksudkan untuk menguji validitas butir tes instrumen secara empiris atau berdasarkan data empiris yang diperoleh dari uji-coba. Validitas yang akan diuji pada pembahasan ini adalah validitas yang menggunakan kriteria internal, yaitu skor total tes sebagai kriteria. Skor total tes dapat digunakan sebagai kriteria untuk menentukan validitas butir instrumen karena secara teoretis atau konsep isi perangkat tes yang telah dibuat dan diujicobakan sudah dianggap valid.

Selanjutnya untuk mengetahui validitas konstruk dilakukan dengan analisis faktor. Pertama instrumen diujicobakan pada sampel (mahasiswa Program studi Tata Kecantikan yang berjumlah 7 orang), kemudian dilakukan analisis faktor, yaitu dengan mengkorelasikan antar skor item tiap instrumen, dalam instrumen penelitian ini analisis faktor menggunakan bantuan analisis SPSS 10.0 for Windows. Sedangkan pedoman dalam memberikan interpretasi terhadap koefisien korelasi dalam analisis item. Item/butir instrumen mempunyai korelasi positif dengan kriterium (skor total) dan korelasi yang tinggi, menunjukkan bahwa item tersebut mempunyai validitas yang tinggi pula. Biasanya syarat minimum yang dapat dianggap memenuhi syarat adalah $\mathrm{r}=0,30$, jika korelasi antar butir instrumen dengan skor total kurang dari 0,30 maka butir tersebut tidak valid dan menunjukkan adanya korelasi yang lemah, dan selanjutnya butir itu digugurkan.

Sedangkan penghitungan reliabilitas instrumen menggunakan kaidah Cronbach alpha, dengan mencari koefisien reliabilitas gabungan. Menurut Thorndike dan Hagen (Fernades, 
1984), bila instrumen menggunakan skala likert, indek reliabilitasnya dapat dihitung dengan koefisien alpha dari Cronbach dan kriteria instrumen yang reliabel ditunjukkan oleh koefisien reliabilitas lebih atau sekurang-kurangnya 0,5. Reliabilitas instrumen pada penelitian ini dilakukan dengan menggunakan bantuan analisis SPSS 10.0 for Windows.

Dari hasil analisis diperoleh nilai koefisien korelasi antara skor butir dengan skor total untuk semua butir dari masing-masing instrumen yang disebutkan di atas menunjukkan nilai lebih besar dari 0.30, maka semua butir mempunyai korelasi signifikan dengan skor total tes. Dengan demikian maka semua butir tes dianggap valid atau dapat digunakan untuk mengukur hasil belajar. Selanjutnya koefisien reliabilitasnya masing-masing instrumen adalah : (a) Instrumen Tes Kinerja Merias Wajah Sehari-hari diperoleh koefisien alpha sebesar 0,6938. (b) Instrumen Tes Kinerja Perawatan Kulit Kepala dan Rambut diperoleh koefisien alpha sebesar 0,6826. (c) Instrumen Tes Kinerja Penataan Rambut (sanggul) Kombinasi Tradisional dan Modern diperoleh koefisien alpha sebesar 0,6502. (d) Instrumen Tes Kinerja Melakukan Perawatan Tangan (manicure) diperoleh koefisien alpha sebesar 0,6617. (e) Instrumen Tes Kinerja Melakukan Perawatan Kaki (padicure) diperoleh koefisien alpha sebesar 0,5741. Sehingga instrumen asesemen tersebut dapat dikatakan reliabel dan layak digunakan untuk mengukur hasil belajar mahasiswa.

Instrumen yang sudah mengalami perbaikan pada tahap uji panelis dan selanjutnya diuji validitas dan reliabilitasnya secara empiris selanjutnya dapat direkomendasikan untuk digunakan sebagai instrumen asesemen untuk mengukur proses dan hasil belajar mahasiswa. Langkah selanjutnya adalah merakit instrumen menjadi asesemen tes yang sebenarnya dan melakukan reproduksi sesuai dengan kebutuhan.

\section{b. Prosedur Penggunaan Intrumen Asesemen}

Setelah dilakukan uji coba pada sejumlah sampel dapat diperoleh gambaran prosedur penggunaan instrumen tergolong praktis, pasti dan mampu memberikan motivasi kepada mahasiswa untuk lebih berusaha untuk melakukan pekerjaan/ kinerja yang terbaik. Hal ini dikarenakan instrumen asesemen yang digunakan secara langsung dapat mengukur kinerja yang sebenarnya harus diukur dari aspek-aspek kinerja yang diharapkan, bahkan mahasiswa telah mengetahui aspek-aspek yang akan diukur/ dinilai. Hal ini sesuai dengan prinsip dari asesemen otentik yang dikembangkan. Jadi dalam penggunaan instrumen asesemen ini ditetapkan langkah-langkah penggunaannya sebagai berikut. Menginformasikan kepada semua mahasiswa tentang pelaksanaan asesemen mata kuliah, mempersiapkan perkuliahan dengan baik dan melakukan persiapan penilaian menggunakan asesemen yang sesuai, melaksanakan asesemen kinerja secara seksama melalui pengamatan dengan menggunakan instrumen asesemen yang telah disiapkan terhadap kinerja mahasiswa, jika tidak memungkinkan oleh karena jumlah

JPTK, UNDIKSHA, Vol. 11, No. 2, Juli 2014 : 63 - 74 
mahasiswa yang terlalu banyak, maka dapat dilakukan dengan tim pengajar, melakukan analisis hasil penilaian, melakukan tindak lanjut hasil penilaian, dan melakukan keputusan penilaian dengan menggabungkan hasil penilaian dengan menggunakan alat penilaian lain disamping instrumen asesemen kinerja ini.

\subsection{Pembahasan}

Dari beberapa langkah penyusunan dan pengembangan perangkat instrumen asesmen Praktek Tata Busana yang dilaksanakan, diperoleh seperangkat asesmen penilaian yang terdiri dari 5 perangkat tes yang telah memiliki validitas dan reliabilitas yang dapat diandalkan.

Pada tahap pertama dilaksanakan studi kepustakaan dan kajian empirik dengan maksud agar dalam penyusunan butir tes memiliki struktur dan landasan pengukuran yang kuat dan sesuai dengan kebutuhan pengukuran. Selanjutnya dikembangkan kisi-kisi instrumen dan penyusunan draft perangkat asesmen. Draft perangkat asesmen ini dikonsultasikan dengan ahli atau expert dalam bidang evaluasi dan dalam bidang tata rias. Selanjutnya dilakukan uji coba dengan maksud agar instrumen tes yang disusun memiliki validitas dan reliabilitas tes yang dapat diandalkan sesuai dengan maksud penggunaan instrumen.

Validitas instrumen dilakukan terhadap validitas isi dan validitas konstruk. Validitas isi dimaksudkan untuk mengetahui sejauhmana instrumen mencerminkan isi yang dikehendaki. Validitas konstruk mengarah pada sejauhmana instrumen mengukur sifat bangunan pengertian atau konstruk tertentu (Furchan, 1982). Validitas isi terhadap perangkat instrumen dalam hal ini dilakukan dengan mengkonsultasikan dengan para ahli dan pembimbing (judgment experts). Melalui judgment expert's ini dapat diketahui apakah setiap butir instrumen telah menggambarkan indikator dari setiap variabel secara teori atau belum, selanjutnya diperoleh instrumen yang dapat memenuhi dan mencerminkan keseluruhan isi yang hendak diukur.

Langkah selanjutnya dilakukan penyempurnaan perangkat instrumen. Dalam penyempurnaan ini dilakukan penyempurnaan terhadap penggunaan bahasa dan kalimat yang sesuai dengan kaidah dan penghilangan butir tes yang dianggap tidak valid.

Lebih lanjut dalam pengembangan instrumen asesmen kinerja dibutuhkan prosedur penggunaan asesemen kinerja yang lebih praktis, dan lebih sederhana. Hasil penelitian Wulan (2007) tentang konsep dan prosedur asesmen kinerja yang berlaku selama ini disebutkan terlalu rumit. Sehingga perlu dilakukan penyederhanaan dalam prosedur penggunaan asesemen. Lebih lanjut disebutkan dalam reformasi asesmen kinerja di Indonesia perlu dilakukan penyederhanaan konsep, prinsip dan prosedur asesmen, dan penelitian asesmen di masa datang perlu mengacu pada konsep asesmen yang lebih simple. 


\section{SIMPULAN DAN SARAN}

Berdasarkan hasil penelitian dan pembahasan yang telah dilakukan, diperoleh simpulan sebagai berikut. 1) Rancangan perangkat instrumen Mata Kuliah Praktek Tata Rias dikembangkan melalui tahap analisis kebutuhan instrumen yang dilakukan melalui kajian pustaka dan kajian terhadap kompetensi mata kuliah dengan melibatkan tim peneliti dan pengampu mata kuliah, kajian ini menghasilkan kisi-kisi perangkat instrument dan perangkat instrument beserta pedoman penskorannya. Perangkat instrument tersebut terdiri dari: langkah validitas asesmen dilakukan melaui tahap : 1) dikonsultasikan kepada ahli (expert), uji empiris untuk membuktikan validitas dan reliabilitas perangkat instrumen asesemen yang dirancang. 2) Prosedur Penggunaan Perangkat Instrumen Asesmen Mata Kuliah Praktek Tata Busana masih terlalu rumit sehingga diperlukan konsep penyederhanaan prosedur penggunaan asesemen yang mengarah kepada prosedur yang praktis dan efisien.

Dengan melihat hasil penelitian dan pembahasan, dapat disarankan/ direkomendasikan beberapa hal sebagai berikut. 1) Dalam pengembangan instrumen penilaian suatu mata kuliah dapat ditempuh langkah-langkah yang telah peneliti lakukan dan perlu melibatkan berbagai pihak seperti ahli evaluasi, ahli konten/ bidang studi maupun praktisi, selanjutnya dilakukan uji validitas dan reliabilitas. 2) Asesemen yang dikembangkan harus disusun secara komprehensip baik dari segi isi/ materi asesemen yang dapat mewakili semua kompetensi dasar maupun indikator yang harus diukur maupun dari bentuk asesemen dan jenis tagihannya. 3) Di tahun berikutnya penelitian ini agar dapat dilanjutkan untuk mengembangkan prosedur asesemen yang lebih sederhana dan lebih praktis tanpa mengurangi makana dan maksud penggunaan asesemen.

\section{DAFTAR PUSTAKA}

Adnyana. P.B. 2005. Penilaian dalam Kurikulum Berbasis Kompetensi. Makalah Disajikan dalam Penataran Guru-guru SMP dan SMA Se-Kabupaten Jembrana. Tidak dipublikasikan

Depdiknas. 2004. Kerangka Dasar Sistem Penilaian Hasil Belajar Peserta Didik SMK. Direktorat Pendidikan Menengah Kejuruan. Depdiknas

Fuchs, L.S. 1995. Connecting performance assessment to instruction: A comparison of behavioral assessment, mastery learning, curriculum-based measurement and performance assessment. ERIC Digest E530.

Ana Ratna Wulan. 2007. Skenario Baru Bagi Implementasi Asesemen Kinerja Pada Pembelajaran Sain di Indonesia. Artikel. FPMIPA Universitas Pendidikan Indonesia

Sudirtha, I Gede. Partisipasi Dunia Usaha dan Dunia Industri Dalam Pendidikan Kejuruan Studi Pada Pelaksanaan Praktik Industri Siswa SMK Negeri Di Provinsi Bali Bidang Keahlian Tata Busana. Artikel. Jurnal Pendidikan dan Pengajaran IKIPN Singaraja ISSN 0215-8250 Volume 39 No.2 April 2006.

JPTK, UNDIKSHA, Vol. 11, No. 2, Juli 2014 : 63 - 74 
Sudirtha, I Gede. Implementasi Pembelajaran Berbasis Produksi melalui Media dan Sumber Belajar Kontekstual dalam Meningkatkan Kualitas Hasil Belajar Desain Busana Mahasiswa Pendidikan Tata Busana FPTK IKIP Negeri Singaraja. Artikel, Jurnal Pendidikan dan Pengajaran Universitas Pendidikan Ganesha ISSN 0215-8250 Volume 40 No.1 Januari 2007

Soeprijanto, 2010. Pengukuran Kinerja Guru Praktek Kejuruan. Konsep dan Teknik Pengembangan Intrumen. Jakarta: PT. Tursiana

Yoyoh Jubaedah. 2009. Model Penilaian Kompetensi Tata Busana Berbasis Standar Kompetensi Nasional di Sekolah Menengah Kejuruan. Desertasi. Bandung : Sekolah Program Pascasarjana UPI. 
JPTK, UNDIKSHA, Vol. 11, No. 2, Juli 2014 : 63 - 74 